\title{
Metodologie etymologii
}

\section{Jacek Perlin}

Uniwersytet Warszawski

Pod pojęciem etymologii, czyli pochodzenia wyrazu, rozumie się albo historyczną ciągłość między jego końcową dla nas postacią a jej najbliższym zaświadczonym historycznym poprzednikiem, albo relację między końcową postacią wyrazu a jej prehistoryczną zrekonstruowaną formą lub kolejnymi formami z następujących po sobie faz rozwoju języka. W każdym wypadku poprzednik badanego wyrazu może być określony nazwą etymonu.

Każde wskazanie etymonu jest hipotezą — jak wszystko w naukach empirycznych. Niekiedy hipotezę można uznać za graniczącą z pewnością, zwłaszcza gdy przejście od etymonu do wyrazu badanego odbywa się na naszych oczach; niekiedy stopień prawdopodobieństwa sformułowanej hipotezy jest bardzo niski.

Przypadek relacji między końcową postacią a najbliższym poprzednikiem ma zastosowanie głównie przy zapożyczeniach. Na przykład etymonem polskiego rzeczownika lampa jest albo francuskie lampe, albo niemieckie Lampe, albo oba naraz. Dotyczy to również kalk semantycznych, np. wyraz dowolny w znaczeniu 'jakikolwiek' jest prawdopodobnie naśladowaniem łacińskiego zwrotu ad libitum. Czasami historycznie zaświadczona forma podawana jest też przy wyrazach niezapożyczonych, ale zmienionych w wyniku ewolucji fonetycznej lub znaczeniowej, np. polskie być od byti, biegun w znaczeniu 'punkt na globusie' albo 'płoza' od osobowego biegun znaczącego niegdyś 'zbieg, dezerter'. Podawanie historycznego etymonu jest zwykłą praktyką w etymologii języków wywodzących się od dobrze znanego prajęzyka, np. w słownikach języków romańskich, również nieetymologicznych, podawany jest zwykle łaciński odpowiednik, niezależnie od tego, czy wyraz jest odziedziczony, czy zapożyczony z łaciny.

Przypadek odwoływania się do etymonu zrekonstruowanego ma zastosowanie zwłaszcza w językach, których przodek nie jest historycznie zaświadczony, a także w badaniach sięgających głęboko w przeszłość. Na przykład najdalszym podawanym etymonem polskiego być jest indoeuropejski pierwiastek *bhü/bheu. W wielu słownikach etymologicznych pochodzenie wyrazu podaje się $\mathrm{w}$ obu opisanych znaczeniach.

W słownikach etymologicznych podaje się też z reguły określenia dotyczące stopnia prawdopodobieństwa hipotez. Przykładowo mogą występować przysłówki chyba 
lub zapewne, w odniesieniu do hipotez, które autor uważa za bardziej prawdopodobne od innych, oraz może - gdy dana hipoteza jest traktowana jako nie całkiem nieprawdopodobna. Niektórzy autorzy używają jeszcze przysłówka oczywiście, gdy uważają hipotezę za jedyną możliwą do przyjęcia. Inne używane określenia to wyraz etymologicznie jednoznaczny - w odniesieniu do którego da się udowodnić wyższość jednej z hipotez etymologicznych nad pozostałymi oraz wyraz etymologicznie wieloznaczny, jeżeli wyższości żadnej z istniejących hipotez nie da się udowodnić.

$\mathrm{W}$ ocenie etymologicznych hipotez przyjęte są pewne metodologiczne zasady, z których najważniejsze omówimy poniżej.

Pierwszą z nich jest zasada transcendencji historycznej. Zakłada ona, że przyjęcie hipotezy o powstaniu wyrazu przez derywację implikuje konieczność wyjaśnienia wcześniejszego pojawienia się wyrazu, od którego badany wyraz został derywowany. A zatem założenie, że wyraz banat jest derywacją wsteczną od banalny narzuca konieczność uznania, że wyraz banalny pojawił się wcześniej jako pożyczka (najprawdopodobniej od francuskiego banal).

Kolejna zasada, kompletności hipotezy, zakłada potrzebę wyjaśnienia wszystkich szczegółowych faktów językowych, a zwłaszcza wszystkie nieoczywiste różnice między rozpatrywanym wyrazem a jego domniemanym etymonem. Dla przykładu hipoteza, że rumuński wyraz canísa 'zakład hodowli psów' pochodzi bezpośrednio od łacińskiego canis 'pies' nie wyjaśnia zmiany znaczenia, przeniesienia akcentu, zmiany rodzaju i przybrania końcówki. Natomiast hipoteza, że canisă pochodzi od nazwy konkretnej francuskiej firmy hodowlanej o nazwie Canis (choć o jej rzeczywistym istnieniu nic nie wiadomo) da się rozłożyć na szereg spójnych hipotez częściowych, wyjaśniających wszystkie wymienione zmiany. Owe hipotezy częściowe byłyby następujące:

— Twórcy francuskiej firmy zapożyczyli łaciński wyraz canis, który w naturalny sposób wymawiali z akcentem na ostatniej sylabie.

—Zmienili znaczenie wyrazu z appellativum 'pies' na nazwę własną.

— Nazwa musiała przybrać rodzaj żeński zgodnie z zasadami francuskiej gramatyki (imiona własne firm i instytucji są w tym języku zawsze femininami).

- Rumuni zapożyczyli nazwę firmy i nadali jej rozszerzone znaczenie każdego zakładu tego rodzaju.

— Dodali końcówkę żeńską -ă, według analogii do innych rumuńskich femininów.

Zasada wyjaśnienia i lokalizacji procesu przyjmuje, że każda hipoteza, czy to częściowa, czy kompletna, zakładająca istnienie jakiegoś procesu, powinna być - w miarę możności - wyjaśniona przez podanie okoliczności jego wystąpienia, lokalizacji, nacisków systemowych, uwarunkowań psychologicznych, socjologicznych i innych pozajęzykowych. Polacy zapożyczyli wyraz bryza z francuskiego (może też niemieckiego, co nie zmienia istoty procesu) brise i wyraz krawat z francuskiego cravatte. W obu wypadkach doszło do istotnych procesów transformacyjnych, każdorazowo innych. W pierwszym przypadku dodanie końcówki - $a$ daje się wytłumaczyć faktem adaptacji wyrazu o rodzaju żeńskim do polskiej morfologii, w drugim — zmiana rodzaju z żeńskiego na męski - jego dopasowaniem do spółgłoskowego zakończenia. Tak różne potraktowanie wyrazów analogicznych pod względem zakończenia i rodzaju gramatycznego można interpretować w ten sposób, że bryzę zaadaptowały do polszczyzny osoby znające francuski i zdające sobie sprawę z jego żeńskiego rodzaju, a krawat przeciwnie - ludzie nieznający tego języka, a więc wyobrażający sobie ro- 
dzaj rzeczownika krawat na podstawie jego spółgłoskowego zakończenia i znaczenia nieosobowego. Oczywiście proces adaptacji musiał być poprzedzony użyciem tego wyrazu przez osoby znające francuski, jednak to nie one zaadaptowały go do języka polskiego.

Lepsze wyjaśnienie istoty procesu może stanowić o wyższości wywodu danej hipotezy etymologicznej nad inną. Dwie konkurencyjne hipotezy o pochodzeniu wyrazu fuzja wymieniają francuskie etymony fusil 'strzelba' i fusée 'rusznica'. Obie wyjaśniają pojawienie się zakończenia - $a$ interpretacją francuskich zakończeń - $i$ oraz -e jako końcówek polskich przypadków zależnych. Jedynie natomiast hipoteza wywodząca fuzję od fusil wyjaśnia pojawienie się joty, które w drugiej hipotezie pozostaje zagadką. Oczywiście brak wyjaśnienia nie przesądza o tym, że hipoteza jest bezwartościowa. Istnieją poważni etymolodzy, którzy stanowczo upierają się przy pochodzeniu fuzji od fusée.

Stosowane są też wywody na bazie słowotwórczej i formotwórczej (odwołujące się do procesów dekompozycji i analogii). Wiele postaci wyrazowych niezrozumiałych na pierwszy rzut oka można próbować wyjaśnić procesami słowotwórczymi, dekompozycjami i analogiami. Polski wyraz kajet od francuskiego cahier ma zakończenie $t$ prawdopodobnie $\mathrm{w}$ wyniku kontaminacji pierwotnego kaje z karnet.

Procesy etymologiczne stanowiące wyjaśnienie ewolucji dają się sklasyfikować. Wyróżniamy w nich takie kategorie, jak: naturalizacja, czyli adaptacja zapożyczonego wyrazu do systemu języka. Jest to najprostszy z istniejących procesów. A zatem kształt polskiego wyrazu biuro pochodzącego z francuskiego bureau, który został naturalizowany przez przesunięcie akcentu, zmianę rodzaju i zamianę [ü] na [ju] łatwo jest wytłumaczyć wymaganiami polszczyzny, w której wyrazy są normalnie akcentowane na przedostatniej sylabie, rzeczowniki na -o są rodzaju nijakiego i nie istnieje fonem $/ \ddot{\mathrm{u}} /$.

Inny naturalny proces to społeczne unormowanie, które wyjaśnia uznanie określonego wariantu za gorszy i w konsekwencji jego eliminację, np. w języku polskim z konkurujących w swoim czasie form jenerat i generat zwyciężyła ta druga, gdyż formy bardziej zbliżone fonetycznie do łacińskich cieszyły się większym prestiżem. To samo stało się (znacznie wcześniej) z równoległymi formami japoszczol i apostol.

Zmiany znaczenia wyrazów mogą być powodowane ograniczeniem kontaktów międzyśrodowiskowych prowadzących do zwyczajnych nieporozumień. W wielu językach występuje wyraz (oczywiście w różnych wersjach fonetycznych) aperitif, oznaczający pierwotnie napój alkoholowy podawany na początku przyjęcia na pobudzenie apetytu - przede wszystkim gorzki likier ziołowy. W większości języków, które przejęły ten wyraz zaczął on oznaczać albo jakikolwiek słaby napój alkoholowy (np. w polskim), albo napój alkoholowy lub podawaną wraz z nim przekąskę (np. w hiszpańskim), wreszcie wyłącznie przekąskę (np. w rumuńskim). Procesy te dają się wytłumaczyć sytuacją przekazywania wyrazu nowemu środowisku społecznemu. Przede wszystkim poznawało ono jego znaczenie w drodze poglądowej, a nie w drodze definicji. Po drugie przekazanie wyrazu musiało odbywać się w sytuacji, w której napój aperitif konsumowano jednocześnie z przekąską. Po trzecie wreszcie, dla środowiska przejmującego - w przeciwieństwie do przekazującego — właśnie przekąska stanowiła widocznie najistotniejszy element sytuacji.

Hipotetyczne procesy ewolucyjne są klasyfikowane również z perspektywy charakteru przesłanki. Dzielą się one na: naturalne adaptacje do systemu języka zapożyczającego, 
czyli procesy automatyczne; procesy systemowe, w których zachodzi konieczność wyboru, czyli podjęcia mniej lub bardziej świadomej decyzji o sposobie zaadaptowania pożyczki. Najczęściej można w nich dopatrzyć się zjawiska przesłanki polegającej na istnieniu wyrazów pozwalających na ustanowienie proporcji językowej. W polskim istnieje szereg przymiotników zakończonych na -czny lub -cki, zapożyczonych z języków zachodnioeuropejskich, w których mają odpowiedniki: niemiecki na -isch, łaciński na -icus, francuski na -ique, np. poetycki, hanzeatycki, nordycki, dramatyczny, tragiczny, logiczny. Wybór końcówki -czny lub -cki, a nie dajmy na to -owy, -ski uzasadnia występowanie wyrazów już istniejących, tworzących proporcję etymologiczną oraz pewne podobieństwo formalne końcówek, które musiało być decydujące przy pierwszej pożyczce inicjującej serię (może publiczny od publicus i poetycki od poeticus). A zatem utworzenie nowego wyrazu hanzeatycki motywowane było istnieniem wyrazów typu dorycki, semicki, a wyrazu semantyczny istnieniem wyrazów typu logiczny, filozoficzny. Wybór tej, a nie innej końcówki był jednocześnie spowodowany proporcją paronimiczną, a więc wyrazy oznaczające pochodzenie etniczne czy geograficzne łączyły się raczej ze -cki, a odnoszące się do działów wiedzy raczej ze -czny. Innego rodzaju typ proporcji paronimicznej przedstawia utworzenie wyrazu samolot według modelu samochód.

Istnieją przypadki powstania neologizmów w wyniku procesów opartych na proporcji, ale nie automatycznych ani systemowych, ale sztucznych, wymagających specjalistycznej wiedzy językowej i refleksji osoby tworzącej neologizm. Hiszpański przymiotnik bonaerense 'pochodzący z Buenos Aires' powstał przez zastosowanie proporcji członów nazwy do ich łacińskich odpowiedników: bueno - bonus, aire - aer i dodaniu sufiksu -ense. Bardzo dobrym przykładem procesu sztucznego są kalki semantyczne, motywowane istnieniem proporcji homonimicznej, więc np. zbudowanie niemieckiego Fernsehen według proporcji tele $=$ fern, visio $=$ sehen.

Procesy międzyjęzykowe również mogą tłumaczyć szereg zjawisk etymologicznych. Najprostszym przypadkiem procesu międzyjęzykowego jest zwykłe zapożyczenie wyrazu. Może on funkcjonować albo w postaci cytatu — bez adaptacji, jak wyraz attaché, podlegać automatycznej adaptacji, jak wyraz biuro, adaptacji systemowej, jak wyraz komiczny, wreszcie adaptacji sztucznej, jak w wyrazie amalgamat z francuskiego amalgame, przez analogię do aromat. Zdarzają się też rzadsze znacznie zapożyczenia morfemów słowotwórczych, a nawet — wyjątkowo — form fleksyjnych. W języku polskim ciekawym przypadkiem jest zapożyczenie łacińskiego wołacza w imieniu Jezus Chrystus, który ma postać Jezu Chryste.

Hipotezy częściowe mają różną wartość. Chociaż teoretycznie dopuszczalne są wszelkie ich rodzaje, to jednak w praktyce pewne typy hipotez zmniejszają siłę przekonującą hipotezy historyczno-leksykalnej, w skład której wchodzą, a zatem mają charakter ryzykownych. Z kolei hipotezy, które nie zmniejszają siły przekonującej całego wywodu, mają charakter bezpiecznych. Przykładowo: rumuński wyraz colet 'paczka pocztowa' wywodzić można z francuskiego colis 't.s.', przy założeniu kontaminacji z rumuńskim pachet 'paczka', albo z włoskiego colletto lub nowogreckiego koleto 't.s.' Pierwszą z tych hipotez należy uznać za ryzykowną, a drugą za bezpieczną, gdyż odwołuje się ona do procesu adaptacji automatycznej. Oprócz tego istnieją hipotezy bezproblemowe, które nie dość, że odwołują się do procesów automatycznych, to jeszcze nie mają konkurencji w postaci innych teorii. Taką bezproblemową hipotezą jest wywodzenie wyrazu maltretować z francuskiego maltraiter. Nie jest natomiast bezproblemowe wywodzenie wyrazu lampa, który może pochodzić albo 
$\mathrm{z}$ niemieckiego Lampe, albo z francuskiego lampe. Wprawdzie obie hipotezy są bezpieczne, gdyż nie zawierają żadnych nieregularności w procesie adaptacji wyrazu do polszczyzny, jednak nie dają żadnej przesłanki do uznania którejś z nich za bardziej prawdopodobną. Jedynie sformułowanie „wyraz lampa został zapożyczony albo z francuskiego, albo z niemieckiego", jest całkowicie bezproblemowe.

Hipotezy, które nie są bezproblemowe, a więc wszystkie ryzykowne i niektóre bezpieczne, określa się jako problematyczne. Problematyczność hipotezy może mieć charakter metodologiczny, kiedy odwołuje się do procesu, który nie daje się w sposób oczywisty wyjaśnić, jak pochodzenie giełda od gilda (może przejście $i$ w $e$ według dawnej oboczności kobeta/kobyla?), czy pochodzenie rzeczownika hantle, który wywodzi się od hang-halter, albo charakter historyczny, jak w wypadku wyrazu giermek, który z braku lepszej teorii wywodzi się z węgierskiego gyermek 'dziecko', z dziwaczną zmianą semantyczną. Przykładem hipotez problematycznych zarówno metodologicznie, jak historycznie, jest próba znalezienia etymologii wyrazu herb. Istnieją w tej kwestii dwie teorie: etymonem słowa utworzonego w staroczeskim jest średnio -górno-niemiecki wyraz erbe 'spadkobierca', skontaminowany z łacińskim heres 't.s.', albo też jest to przekształcenie czeskiego hrb 'garb'.

Hipoteza problematyczna zyskuje na wiarygodności, gdy jest podbudowana jakimś wyjaśnieniem, który tłumaczy wystąpienie nieregularnego procesu. Pochodzenie wyrazu burta od niemieckiego bord, z niezrozumiałym przejściem $o \mathrm{w} u$, daje się wyjaśnić wystąpieniem podobnego przejścia w kilku innych wyrazach, jak burdel < bordel, burak < borak. Takie podbudowanie za pomocą paralel szczególnie uwiarygodnia wywód. W przypadku braku seryjnych paralel można poszukać precedensu, czyli wystąpienia podobnej zmiany przynajmniej w jeszcze jednym wyrazie. $\mathrm{Na}$ przykład rumuński wyraz pasarelă 'trap okrętowy' daje się wywieść z francuskiego passerelle, włoskiego passerella lub hiszpańskiego pasarela. Hipoteza hiszpańska jest skrajnie ryzykowna historycznie, natomiast wywód z francuskiego i włoskiego ryzykowne metodologicznie, gdyż nie tłumaczą przejścia $e \mathrm{w} a$. Dają się jednak podbudować precedensem w postaci zaświadczonych zmian samogłoskowych typu A-U-Ú > A-A-Ú, np. w wyrazie conţopist < conţipist.

Istnieją wreszcie hipotezy problematyczne dokumentacyjnie, które zakładają istnienie ewolucji od znaczenia nie zaświadczonego w żadnym źródle. Wywodzenie rumuńskiego wyrazu meditație 'korepetycja' od łacińskiego meditatio 'uczenie się' zakłada istnienie w jakiejś fazie rozwoju języka rumuńskiego wyrazu meditație w pierwotnym znaczeniu etymologicznym, co nie jest nigdzie zaświadczone. Hipoteza ta ma jednak wyższość nad hipotezami konkurencyjnymi, przyjmującymi zapożyczenie wyrazu z któregoś z języków zachodnioeuropejskich, albowiem ma on w nich znaczenie 'medytacja', z której bardzo trudno przejść do 'korepetycji'.

Najwyższą wartość dowodową mają oczywiście hipotezy bezproblemowe, niżej w hierarchii plasują się hipotezy bezpieczne, a jeszcze niżej ryzykowne. Spośród ryzykownych najwyższą wartość mają podbudowane, dalej idą ryzykowne historycznie, a najniżej sytuują się ryzykowne metodologicznie. Całkowicie pozbawione wartości naukowej mają, niekiedy formułowane i często funkcjonujące w społecznej świadomości, hipotezy fantastyczne, jak wywodzenie nazwy Warszawa od rzekomych imion Wars i Sawa, czy nazwy Kraków od imienia króla Kraka.

Wiarygodność całej hipotezy jest sumą wartości jej hipotez częściowych. Zatem o wzajemnym stosunku dwóch konkurujących z sobą hipotez historyczno-leksykal- 
nych decydują zawarte w nich hipotezy częściowe ryzykowne. Polski wyraz egzamin może być wywodzony z łacińskiego examen i francuskiego examen. Przewaga pierwszej z nich polega na tym, że przy wywodzie z łaciny daje się wytłumaczyć zastąpienie $e$ przez $i$, które występuje $\mathrm{w}$ łacinie $\mathrm{w}$ przypadkach zależnych examinis, examina itd. Adaptowanie wyrazów łacińskich do polszczyzny na bazie tematu przypadków zależnych ma przy tym zaświadczoną tradycję (np. pacjent od paciens, Jowisz od Iupiter, Iovis, Wenera od Venus, Veneris itp.). Natomiast przy założeniu pożyczki z francuskiego nie można wskazać procesu, który by przekształcał francuskie zakończenie -en w -in. Wyraz docent z kolei można wywodzić z łacińskiego docens, docentis 'uczący' i niemieckiego dozent 'wykładowca uniwersytecki z doktoratem, bez tytułu profesora’. Oczywiście bardziej wiarygodna jest druga hipoteza, która nie zakłada żadnej skomplikowanej ewolucji semantycznej. Z dwóch hipotez dotyczących pochodzenia rumuńskiego wyrazu afet 'laweta', lepsza jest hipoteza zakładająca, że etymonem jest francuski wyraz affût, niż hipoteza wywodząca formę z rosyjskiego lafet. Pierwsza z nich zakłada jedynie ryzykowne dokumentacyjnie istnienie niezachowanej formy "afit, która następnie została przekształcona w afet na zasadzie atrakcji leksykalnej do licznych wyrazów o tym zakończeniu; druga natomiast zakłada zupełnie niewytłumaczalny i nigdzie niezaświadczony proces elizji początkowego $l$.

W wypadku istnienia dwóch konkurencyjnych hipotez jednakowo ryzykownych merytorycznie można odwołać się do dodatkowych hipotez częściowych historycznych. Rumuński wyraz platan 'szalka wagi' może pochodzić z francuskiego plateau lub hiszpańskiego platillo. Obie zakładają niezrozumiały proces przekształcenia końcowego -eau lub -illo w -an, jednak hipoteza zakładająca pożyczkę z francuskiego jest lepsza, gdyż nie jest ryzykowna historycznie, jako że język ten jest źródłem licznych zapożyczeń do rumuńskiego, podczas gdy hiszpański jako taki nie jest zaświadczony.

Zdarza się, że dwie konkurencyjne hipotezy są zrównoważone bez reszty. Tak jest w wypadku polskiego wyrazu językoznawstwo, które może być dosłowną kalką językową albo rosyjskiego jazykoznanije, albo niemieckiego Sprachwissenschaft. Obie hipotezy są jednakowo bezpieczne zarówno merytorycznie, jak i historyczne, gdyż w wieku XIX, kiedy wyraz wszedł do polszczyzny, zarówno niemiecki, jak i rosyjski były obfitym źródłem zapożyczeń. Przykładem hipotez ryzykownych jednakowo zrównoważonych jest próba odnalezienia źródła rumuńskiego wyrazu fante 'goguś, dandys', dla którego istnieją dwa możliwe wywody: z niemieckiego Fant 't.s.', albo z włoskiego fante 'walet w kartach'. Obie zawierają jedną hipotezę częściową ryzykowną. W wywodzie $\mathrm{z}$ niemieckiego jest nią hipoteza zaniku formy singularis fant i dorobienie nowej postaci liczby pojedynczej fante do zachowanego pluralu fanţi, na zasadzie normalnej proporcji. W wywodzie z włoskiego pojawia się ryzykowna historycznie zmiana znaczenia. W sytuacjach takich jak wyżej opisane, wobec jednakowej wartości wszystkich hipotez częściowych, czy to bezpiecznych, czy ryzykownych, omawiane wyrazy należy uznać za etymologicznie wieloznaczne.

Etymologia jest nietypową nauką, gdyż pewna część formułowanych w niej twierdzeń jest wysoce niepewna i często zupełnie inna u różnych badaczy. Zdarzają się przypadki wyrazów wywodzonych w sposób odmienny u autorów każdego z opublikowanych słowników etymologicznych. Na przykład wyraz 'chleb’ Brückner i Boryś wywodzą z pragermańskiego “hlaiba-, podczas gdy Bańkowski stwierdza, że jest „niemożliwa do przyjęcia hipoteza o zapożyczeniu z germańskiego do prasłowiańskiego”. Jego zdaniem ‘chleb’ może mieć związek z sanskryckim rdzeniem kliba-, kla- 
ibya-. Wyraz 'chlew’ według Bańkowskiego i Borsia są pożyczką germańską z pragermańskiego *hlaiwa, podczas gdy Brückner wywodzi go z prasłowa o tym samym pniu co w wyrazach klatka, łacińskim clino, greckim klisiā. Z kolei 'jeż’ według Brücknera pochodzi od pierwistka "egh- 'kłuć, u Borysia od "eǵhi- 'żmija', z wyjaśnieniem, że „pierwotne znaczenie zapewne 'związany ze żmiją, pożerający żmije', nawiązuje do pożytecznego dla ludzi pożerania przez jeże niebezpiecznych gadów”; u Bańkowskiego 'jėz’ również ma pochodzić od “eğh-i-s 'żmija', jednak „...chyba dlatego, że jego długie kolce przypominają małe wężyki, nie zaś dlatego, że chętnie żywi się wężami i jaszczurkami, umiejętnie na nie polując nocą (o czym raczej nie wiedziano w odpowiednio dawnych czasach)". Wyraz 'foch' Brückner tłumaczy jako zgrubienie od fortel, Bańkowsi jako derywat wsteczny od foszki, które wywodzi z rumuńskiego foş-ni, a Boryś nie uwzględnia tego wyrazu w ogóle.

Jednocześnie etymologia jest to nauka, która powoli ulega atrofii z powodu wyczerpania materiału, przynajmniej w odniesieniu do dobrze opisanych języków. Oczywiście jest jeszcze sporo wyrazów o etymologii niejasnej, w których jest pewna szansa znalezienie bardziej niz dotąd przekonujących eksplikacji, jednak ogrom badań i wysiłek do tego potrzebny jest niewspółmierny do efektu, którym może być jedynie drobny artykuł przyczynkarski. Może to skutecznie zniechęcać przyszłych badaczy do poważnego zajęcia się badaniami etymologicznymi. Jest chyba też zupełnie nieprawdopodobne, aby kiedykolwiek zostały odkryte w większej liczbie nieznane dotąd teksty, które mogłyby rzucić światło na nierozstrzygnięte problemy pochodzenia wyrazów. Języki oczywiście nieuchronnie ewoluują, pojawiają się w nich nowe słowa, a dotychczas używane zmieniają znaczenie, niemniej odbywa się to na naszych oczach, jest na bieżąco rejestrowane i opisywane, co wymaga innych metodologii niż tradycyjna etymologia.

\section{Bibliografia}

Bańkowski, A., 2000, Etymologiczny stownik języka polskiego, tom 1 A-K, t. II P-L, Warszawa: Wydawnictwo Naukowe PWN.

Boryś, W., 2006, Stownik etymologiczny języka polskiego, Kraków: Wydawnictwo Literackie.

Brückner, A., [1927] 1985, Stownik etymologiczny języka polskiego, Warszawa: Wiedza Powszechna.

Boltanski, J. E., 1995, La linguistique diachronique, Paris: Presses universitaires de France.

Perlin. J., 2004, Metodologia językoznawstwa diachronicznego, Warszawa: Wydawnictwo Akademickie Dialog.

Weinsberg, A., 1968, Pochodzenie tzw. „neologizmów” rumuńskich, (maszynopis).

Weinsberg, A., 1983, Jezzkoznawstwo ogólne, Warszawa: Wydawnictwo Naukowe PWN. 